原 著

\title{
若年認知症の発症年齢，原因疾患および有病率の検討 一愛知県における調査から一
}

\author{
小長谷陽子 ${ }^{1 * *}$ 渡邊 $\quad$ 智之 ${ }^{12)} \quad$ 小長谷正明 ${ }^{3)}$
}

\begin{abstract}
要旨 : 愛知県内のすべての医療機関, 介護福祉施設などを対象に，若年認知症の実態調查をおこない，1,092人 （男性 569 人，女性 520 人，性別不明 3 人）について原因疾患と有病率を解析した．調査時平均年齢は $60.7 \pm 7.1$ 歳, 発症年齢は 55.1 \pm 7.8 歳であった. 原因疾患は全体では, アルツハイマー病 (AD) (34.9\%), 血管性認知症 (VD) (34.1\%) が多く, 次いで前頭側頭型認知症 $(5.9 \%)$, パーキンソン病 $(3.6 \%)$ であった. 男性ではVD, AD, FTD, PD の順であり，女性では AD, VD, FTD, PD の順であった. 人口 10 万人当たりの推計有病率は 60 ～ 64 歳で男 性 182.2 人，女性 150.6 人，55～59 歳ではそれぞれ 90.6 人, 81.7 人であった.
\end{abstract}

(臨床神経, 49:335一-341, 2009)

Key words : 若年認知症, アルッハイマー病, 血管性認知症, 疫学調査, 愛知県

はじめに

近年はものわすれ外来などで, 神経内科医が認知症の診療 をする機会が増えてきた。 その中でも最近注目されるように なったのが, 64 歳以下で発症する若年認知症である. 働き盛 りの人におこり，生活や家族への影響が大きいと考えられる が, その実態は明らかでない. 厚生労働省の 1995 年から 1996 年にわたる調查では, 全国で約 26,000 人（18 歳以上 64 歳ま で)と推計されている ${ }^{1)}$ が, 現在でもその正確な数は把握され ていない. もっとも多い原因疾患についてもアルツハイマー 病 $(\mathrm{AD})^{23)}$, あるいは血管性認知症 (VD) とするものなど一 定しない(14)5). また, 近年注目されている前頭側頭型認知症 (FTD) は若年者に多いなど23), 若年認知症の原因疾患は頭部 外傷, 感染症, 脳腫瘍, 神経変性疾患など多様である ${ }^{1)}$ が, 疾 患別の頻度などは明らかにされていない.

既報告では, 特定の病院の特定の診療科のみにおける調査 であったり，一定の地域における調査でも大都市をふくまず， 比較的人口が少ない地域での調査であり, 実態を把握するた めの基礎データとしては十分なものはそし( ${ }^{1)}$-5).

本研究では, 大都市である名古屋市をふくむ愛知県全体を 網羅して, 医療機関のみならず, 介護保険施設, 行政機関をも ふくめた調査をおこなったので報告する.
対象と方法

調査対象は 64 歳以下で発症した認知症とした. 認知症の診 断および程度は Diagnostic and Statistical Manual of Mental Disorders, 3rd edition-revised (DSM-III-R) (American Psychiatric Association, 1987)の診断基準をもちいた. 調査地域 は愛知県全域とした. 調查方法は次に記す方法により, 二段階 でおこなった。

＜第一次調查 $>$ 今回の調査では, 平成 18 年 4 月の時点で 開設されている老人福祉法に基づく施設・居住系サービス事 業所, 知的障害者施設の関連施設, 全病院, 診療所は医師会名 簿記載の診療科のうちで, 下記の診療科を標榜している診療 所および介護療養型医療施設および行政機関などの 5,604 カ 所に対して一次調査表を送付した。

調査の対象は便宜上次の 4 群に分類した. A) 介護保険施設 など(特別養護老人ホーム, 介護老人保健施設, 認知症対応型 グループホーム, 有料老人ホーム), B) 知的障害者施設など (知的障害者更生施設, 授産施設, 通所介護), C) 病院, 診療 所など(全病院および標榜科が精神科, 神経内科, 老年科, 脳 神経外科, 内科の診療所, 介護療養型医療施設), D) 保健所, 社会事務所など(保健所, 社会事務所, 市町村保健センター, 地域包括支援センター，居宅介護支援事業所）である.

調査内容は, 対象となった事業所などにおいて, 平成 18 年 4 月 1 日から同年 9 月 30 日までの 6 カ月間にかかわった

\footnotetext{
${ }^{*}$ Corresponding author: 認知症介護研究・研修大府センター〔テ474-0037 愛知県大府市半月町三丁目 294 番地〕

1)認知症介護研究・研修大府センター

2) 愛知学院大学心身科学部

3) 国立病院機構鈴鹿病院

(受付日：2009年 1 月 28 日)
} 
Table 1 Status of responses for the primary and secondary surveys

\begin{tabular}{|c|c|c|c|c|c|c|c|c|c|}
\hline & \multicolumn{5}{|c|}{ Status of response for the primary survey } & \multicolumn{4}{|c|}{ Status of response for the secondary survey } \\
\hline & $\begin{array}{c}\text { No. of } \\
\text { subject } \\
\text { facilities }\end{array}$ & $\begin{array}{l}\text { No. of } \\
\text { responses }\end{array}$ & $\begin{array}{l}\text { Response } \\
\text { rate (\%) }\end{array}$ & $\begin{array}{l}\text { No. of facilities } \\
\text { caring for peo- } \\
\text { ple with prese- } \\
\text { nile dementia }\end{array}$ & $\begin{array}{l}\text { No. of people } \\
\text { with prese- } \\
\text { nile dementia }\end{array}$ & $\begin{array}{l}\text { Responded } \\
\text { facilities }\end{array}$ & $\begin{array}{l}\text { Response } \\
\text { rate (\%) }\end{array}$ & $\begin{array}{l}\text { No. of people } \\
\text { with prese- } \\
\text { nile dementia }\end{array}$ & $\begin{array}{l}\text { Response } \\
\text { rate (\%) }\end{array}$ \\
\hline $\begin{array}{l}\text { A. Nursing care insurance facili- } \\
\text { ties and similar facilities }\end{array}$ & 790 & 627 & (79.4) & 178 & 416 & 161 & (90.4) & 364 & (87.5) \\
\hline $\begin{array}{l}\text { B. Facilities for mentally re- } \\
\text { tarded persons }\end{array}$ & 522 & 260 & (49.8) & 34 & 59 & 33 & (97.1) & 57 & (96.6) \\
\hline $\begin{array}{l}\text { C. Hospitals, clinics, and similar } \\
\text { facilities }\end{array}$ & 2,551 & 1,429 & $(56.0)$ & 127 & 517 & 103 & $(81.1)$ & 372 & (72.0) \\
\hline $\begin{array}{l}\text { D. Public health centers, wel- } \\
\text { fare offices, and similar facilities }\end{array}$ & 1,741 & 1,173 & (67.4) & 226 & 419 & 212 & (93.8) & 340 & (81.1) \\
\hline total & 5,604 & 3,489 & (62.3) & 565 & 1,411 & 509 & $(90.1)$ & $1,133 *$ & (80.3) \\
\hline
\end{tabular}

*: Number of people before adjusting for overlaps

若年認知症の有無, 性別, 生年月日, 発症年月日である. 本調 查における該当者を明確にするとともに，回答者が医師とは かぎらないことに考慮し, 参考資料として診断基準と診断の 手引きを同封した，調査期間は，2006 年 10 月 25 日から 12 月 12 日までであった.

<第二次調査 $>$ 第一次調査で該当する若年認知症の人が 「いる」と回答した施設や機関に二次調查票を郵送し, 回答を えた. 同一施設または病院で複数の回答があり, 重複している 対象者については調整をおこなった. 調查内容は, 本人の属 性, 認知症の原因疾患, 合併症, 家族歴, 既往歴, 重症度, 就 労状況, 日常生活動作能力, 認知症の行動と心理症状 (Behavioral and Psychological Symptoms of Dementia：BPSD)の有 無と内容, 介護認定状況, サービス利用状況, 障害者手帳 - 年 金受給状況および現在の問題点などである．原因疾患に関し て本調查では, VD, $\mathrm{AD}, \mathrm{FTD}$, パーキンソン病 $(\mathrm{PD})$, 頭 部外傷後遺症, アルコール依存症, 脳腫瘍, 感染症, その他の 選択肢を示した. 回答者は医師とはかぎらないが, 診断につい ては医師が書いた診断書などを基にして選択してもらった。

今回はこれらの調査項目のうち, 若年認知症の人数, 性別, 年齢, 発症年齢, 原因疾患, 有病率について解析した. 若年認 知症の人数に関しては, 対象を 64 歳以下で発症したものとし たため, 調査時点で 65 歳以上の対象者もふくまれる.ただし, 先行研究との比較をした Table 6 のデータについては, 先行 研究のうち記載がない 2 報告を除いて, 対象が調查時点で 64 歳以下のものとされているので, 本研究でもそれにならって 64 歳以下の対象者のみで解析し比較した. 原因疾患について は, 若年認知症の原因疾患として頻度が高い $\mathrm{AD}, \mathrm{VD}$, FTD, PD の 4 疾患を解析の対象とし, これら以外は一括し て「その他」とした，本調査では病名の選択肢として PDのみ とし, レビー小体型認知症（DLB）などのパーキンソン症状 を呈する他の神経変性疾患については, 神経内科医などの専 門医でないと鑑別が困難であると考え, 選択肢としなかった. $\mathrm{PD}$ を選択した対象者は全員, 認知機能低下がみられたので, Table 6 ではPDD/DLB の範疇に入れることとした．また, FTD に関しては, Table 6 の既報告では, 前頭側頭葉変性症
（FTLD）とされているものにほぼ該当すると考えた.

有病率については, 一次調査, 二次調査ともに回収率が $100 \%$ であったと仮定したばあいの推計の人数を, 各年齢層 ごとおよび原因疾患別に算出し, 調査年度の愛知県の人口か ら相当する人口を割り出し, 人口 10 万人当たりの人数を算出 した。

調查期間は, 2007 年 1 月 11 日から平成 19 年 2 月 28 日ま でであった。

\section{結果}

第一次調査では, 対象となった 5,604 の施設や機関のうち, 3,489 の施設や機関から回答をえた。施設を単位とした回収 率は $62.3 \%$ であった。 介護保険施設などでもっとも高く $(79.4 \%)$, 知的障害者施設では低かった $(49.8 \%)$. 若年認知症 が「いる」と回答した施設は 565 であり, 人数は 1,411 人で あった（Table 1).

二次調査では，若年認知症の人が「いる」と回答した 565 の施設や機関のうち 509 の施設や機関から回答をえ, 施設単 位の回収率は $90.1 \%$ であった。この 509 施設において一次調 查時に確認した若年認知症の人は 1,133 人であり，このうち 重複がみられたのは 12 人であり，いずれも 2 施設で記載され ていた（Table 1).

調査においては発症が 64 歳以下であれば, 調査時点で 65 歳以上の人もふくめて集計し, 二次調査で重複などを調整し た後の総数は 1,092 人で, 男性 569 人 $(52.1 \%)$, 女性 520 人 $(47.2 \%)$, 性別無回答 3 人であった。調査時の年齢が 18 歳か ら 64 歳までの若年認知症の人数は 796 人で, 男性 434 人 $(54.5 \%)$ ，女性 361 人 $(45.4 \%)$, 性別無回答が 1 人であった. 以下の解析は Table 6 を除いて, 65 歳以上をふくめた 1,092 人についておこなった結果である.

調査時点での平均年齢は, 全体では $60.7 \pm 7.1($ mean $\pm \mathrm{SD})$ 歳であり, 男性では, $60.3 \pm 7.2$ 歳, 女性では, $61.1 \pm 7.0$ 歳で あった，疾患別では, PD が $64.1 \pm 5.0$ 歳ともっとも高かった (Table 2). 5 歳ごとの年齢に層化して人数をみると, 男女と 
Table 2 Age and age at onset by gender, and diagnosis

\begin{tabular}{|c|c|c|c|c|c|c|}
\hline \multirow[b]{3}{*}{ total } & \multicolumn{3}{|c|}{ age (years old, mean $\pm \mathrm{SD})(\mathrm{N})$} & \multicolumn{3}{|c|}{ age at onset (years old, mean $\pm \mathrm{SD}$ ) (N) } \\
\hline & men & women & total & men & women & total \\
\hline & $60.3 \pm 7.2(612)$ & $61.1 \pm 7.0(555)$ & $60.7 \pm 7.1(1,167)$ & $55.0 \pm 7.7(521)$ & $55.1 \pm 7.9$ & $55.1 \pm 7.8$ \\
\hline $\mathrm{AD}$ & $61.5 \pm 4.7(152)$ & $62.4 \pm 5.2(254)$ & $62.1 \pm 5.1(406)$ & $56.2 \pm 4.9(127)$ & $56.4 \pm 4.8 \quad(221)$ & $56.3 \pm 4.9$ \\
\hline VD & $60.5 \pm 6.4(258)$ & $59.3 \pm 8.4(141)$ & $60.1 \pm 7.2(399)$ & $55.1 \pm 7.7(222)$ & $54.2 \pm 8.8$ & $54.8 \pm 8.1$ \\
\hline FTD & $60.4 \pm 5.8(28)$ & $60.9 \pm 5.5(41)$ & $60.7 \pm 5.6(69)$ & $56.5 \pm 5.4(21)$ & $55.6 \pm 6.8$ & $56.0 \pm 6.2$ \\
\hline PD & $63.6 \pm 4.5(23)$ & $64.7 \pm 5.6(19)$ & $64.1 \pm 5.0(42)$ & $55.9 \pm 5.2(23)$ & $54.0 \pm 6.5$ & $55.0 \pm 5.9$ \\
\hline others & $58.6 \pm 9.8(151)$ & $59.8 \pm 8.5(100)$ & $59.1 \pm 9.4(251)$ & $53.7 \pm 9.9(128)$ & $53.2 \pm 11.4(84)$ & $53.6 \pm 10.5(212)$ \\
\hline
\end{tabular}

AD: Alzheimer's disease, VD: vascular dementia, FTD: frontotemporal dementia, PD: Parkinson disease

Table 3 Number of patients according to age at the present study

\begin{tabular}{llrrrrrr}
\hline age range & gender & AD & VD & FTD & PD & others & total \\
\hline$\leqq 39$ & men & 0 & 1 & 0 & 0 & 6 & 7 \\
& women & 0 & 2 & 0 & 0 & 3 & 5 \\
$40-44$ & men & 0 & 7 & 0 & 0 & 6 & 13 \\
& women & 1 & 3 & 0 & 0 & 4 & 8 \\
$45-49$ & men & 1 & 11 & 1 & 0 & 6 & 19 \\
& women & 3 & 7 & 0 & 0 & 1 & 11 \\
$50-54$ & men & 10 & 15 & 3 & 0 & 17 & 45 \\
& women & 6 & 14 & 7 & 0 & 11 & 38 \\
$55-59$ & men & 40 & 66 & 9 & 6 & 26 & 147 \\
& women & 61 & 40 & 7 & 3 & 22 & 133 \\
$60-64$ & men & 67 & 97 & 9 & 7 & 53 & 233 \\
& women & 96 & 43 & 16 & 6 & 32 & 193 \\
$\geqq 65$ & men & 34 & 61 & 6 & 10 & 37 & 148 \\
& women & 87 & 32 & 11 & 10 & 27 & 167 \\
\hline \multirow{2}{*}{ total } & & 406 & 399 & 69 & 42 & 251 & $1,167 *$ \\
\hline
\end{tabular}

*: The number of total is over the number of actual one because some answers of diagnosis were more than one. AD: Alzheimer's disease, VD: vascular dementia, FTD: frontotemporal dementia, PD: Parkinson disease

も 60 歳〜 64 歳がもっとも多く (233人, 193 人), 次いで 65 歳以上（148 人, 167 人）であった（Table 3$)$.

発症年齢無回答の 181 人を除いた, 発症時の平均年齢は全 体では $55.1 \pm 7.8$ 歳, 男性では $55.0 \pm 7.7$ 歳, 女性では $55.1 \pm 7.9$ 歳であった (Table 2). また, 5 歳ごとの年齢に層化して人数 をみると，男女とも 60 歳〜 64 歳（167 人, 146 人）がもっと も多く, 次いで 55 歳 59 歳 (166 人, 146 人) がほぼ同数で あった（Table 4).

原因疾患に関しては，全体では， $\mathrm{AD}(34.9 \%), \operatorname{VD}(34.1 \%)$ がほほ同数であり, 次いでFTD $(5.9 \%), \mathrm{PD}(3.6 \%)$ の順で あった，男性ではVDがもっとも多く $(42.2 \%)$, 次いで $\mathrm{AD}$ (24.8\%), FTD (4.6\%), PD (3.8\%)であった。女性では AD がもっとも多く(45.8\%), ついで, $\operatorname{VD}(25.4 \%), \operatorname{FTD}(7.4 \%)$, PD (3.4\%) であった（Fig. 1A， B， C).

人口 10 万人当たりの有病者数を 5 歳毎の年齢階層別にみ ると, 男女とも 60 歳 64 歳でもっとも多く (182.2 人, 150.6 人), 次いで 55 歳 59 歳 ( 90.6 人, 81.7 人)であった。 また, 原因疾患別にみると $\mathrm{AD}$ (10.1 人) と VD (9.9 人) の有病率は ほほ同じであり, 次いで FTD (1.7 人), PD（1.0人）あった (Table 5).

\section{考察}

本研究は人口約 730 万人 (平成 18 年 10 月現在) を擁する愛 知県において, 病院や診療所だけでなく, 介護保険関係施設・ 事業所，行政機関をふくめておこなった若年認知症の実態調 査である。

日本の若年認知症に関する調査は多くはないが，今までに いくつかの報告がある ${ }^{1) ~ 5)}($ Table 6). Table 6 のうち, 宮永ら は 3 つの県(青森, 群馬, 徳島)と 2 市を調査区域としており, 朝田は茨城県の調查である。大城らは鳥取県の医療機関に調 査用紙を送ってえた結果である. Yokota ら, Shinagawa らは それぞれの医療機関に一定の期間に受診した患者数を集計し た結果である。

調查方法は 2 通りあり, 今回のように一定の地域の対象機 関に調查票を送付して回答をえるもの (Communitybased）と, 特定の医療機関を受診した患者について一定の期 間を区切って調查したもの (Clinic-based) である。 それぞれ の方法には特徴があり, Community-based では, 選定した地 域や, 対象機関, 回収率によって, 調査の精度が影響される. 
Table 4 Number of patients according to age at onset

\begin{tabular}{|c|c|c|c|c|c|c|c|}
\hline age range & gender & $\mathrm{AD}$ & VD & FTD & $\mathrm{PD}$ & others & total \\
\hline \multirow[t]{2}{*}{$\leqq 39$} & men & 0 & 9 & 0 & 0 & 12 & 21 \\
\hline & women & 1 & 5 & 1 & 1 & 8 & 16 \\
\hline \multirow[t]{2}{*}{$40-44$} & men & 1 & 14 & 1 & 1 & 6 & 23 \\
\hline & women & 3 & 7 & 0 & 0 & 4 & 14 \\
\hline \multirow[t]{2}{*}{$45-49$} & men & 15 & 16 & 2 & 3 & 15 & 51 \\
\hline & women & 16 & 12 & 3 & 4 & 6 & 41 \\
\hline \multirow[t]{2}{*}{$50-54$} & men & 28 & 45 & 4 & 2 & 14 & 93 \\
\hline & women & 51 & 24 & 6 & 4 & 17 & 102 \\
\hline \multirow[t]{2}{*}{$55-59$} & men & 45 & 65 & 6 & 12 & 38 & 166 \\
\hline & women & 83 & 36 & 4 & 4 & 19 & 146 \\
\hline \multirow[t]{2}{*}{$60-64$} & men & 38 & 73 & 8 & 5 & 43 & 167 \\
\hline & women & 67 & 35 & 9 & 5 & 30 & 146 \\
\hline \multicolumn{2}{|c|}{ age at onset unknown } & 58 & 58 & 25 & 1 & 39 & 181 \\
\hline \multicolumn{2}{|l|}{ total } & 406 & 399 & 69 & 42 & 251 & $1,167 *$ \\
\hline
\end{tabular}

*: The number of total is over the number of actual one because some answers of diagnosis were more than one. AD: Alzheimer's disease, VD: vascular dementia, FTD: frontotemporal dementia, PD: Parkinson disease

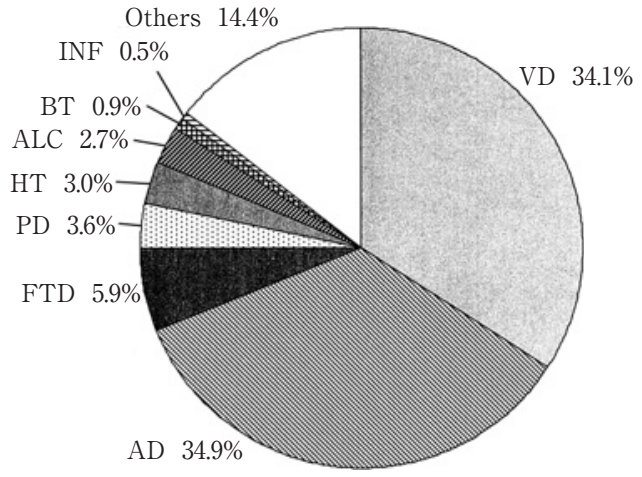

Fig. 1-A Percentage of the diagnosis of dementia in all subjects $(\mathrm{N}=1,092)$

VD: vascular dementia, AD: Alzheimer's disease, FTD: frontotenporal dementia, PD: Parkinson disease, HT: head trauma, ALC: alcoholic dementia, BT: brain tumor, INF: infection.

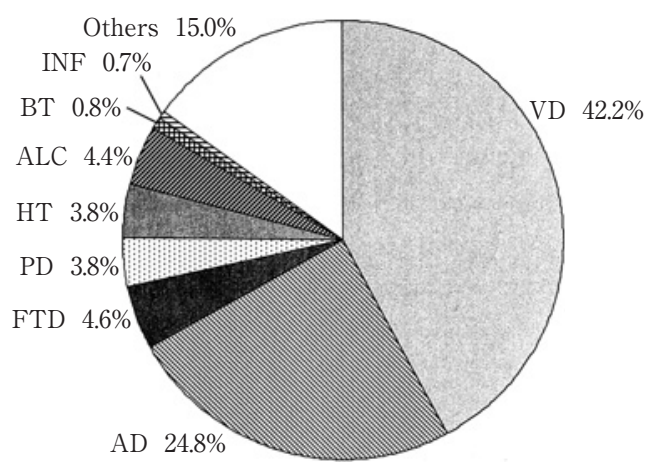

Fig. 1-B Percentage of the diagnosis of dementia in men $(\mathrm{N}=564)$

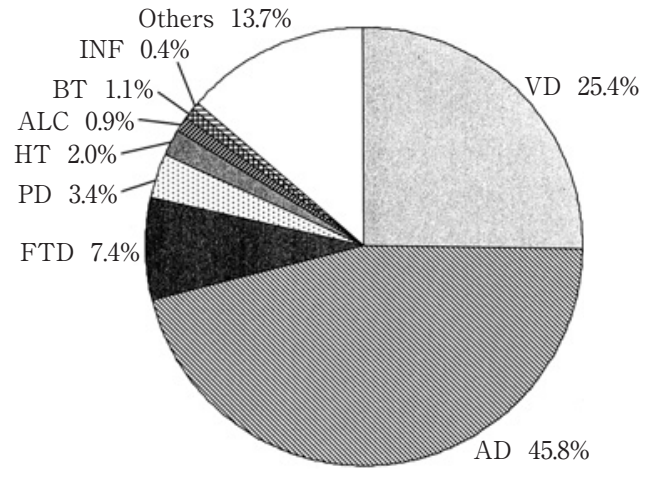

Fig. 1-C Percentage of the diagnosis of dementia in women $(\mathrm{N}=512)$

また, 専門病院以外からの回答では, 診断名などにあいまいさ が残る可能性があるが，一定の地域であまねく若年認知症の 存在を把握することが可能である。一方, Clinic-based では, 医療機関であるので，診断に関しては精度がかなり高いと考 えられるが，診療科によって受診する患者の内容に偏りがあ る。すなわち, 精神・行動障害がめだつような患者は精神科 へ, また, 運動麻疩や言語障害, 錐体外路症状がある患者は神 経内科や脳神経外科へ行くであろう。対象となった医療機関 の規模やその地域での位置づけによっても患者の傾向が左右 される可能性がある.

本調査の限界と課題としては, Community-based の調査で あるため, 原因疾患の診断が, 病院の受診患者を扱った Clinicbased の調查ほど厳密でない点である.しかし, 単に「認知症」 とだけ記されているのではなく, 病名が記されており, 医師に よる診断がなされていると考えられる. Community-based の既報告では回収率は $63.2 \%$ から， $88.3 \%$ であり，大城らの 調査は自施設ではなく, 県内の医療機関にアンケートをした ものであり, 回収率は $52.9 \%$ と高くない. 本研究は, 既報告 
Table 5 Age, gender, and diagnosis specific prevalence rates in study population

\begin{tabular}{|c|c|c|c|c|c|c|c|}
\hline age range & gender & $\mathrm{AD}$ & $\mathrm{VD}$ & FTD & $\mathrm{PD}$ & others & total \\
\hline \multirow[t]{2}{*}{$\leqq 39$} & men & 0.0 & 0.2 & 0.0 & 0.0 & 1.0 & 1.1 \\
\hline & women & 0.0 & 0.4 & 0.0 & 0.0 & 0.5 & 0.9 \\
\hline \multirow[t]{2}{*}{$40-44$} & men & 0.0 & 5.2 & 0.0 & 0.0 & 4.4 & 9.6 \\
\hline & women & 0.8 & 2.4 & 0.0 & 0.0 & 3.2 & 6.3 \\
\hline \multirow[t]{2}{*}{$45-49$} & men & 0.8 & 9.2 & 0.8 & 0.0 & 5.0 & 15.9 \\
\hline & women & 2.6 & 6.2 & 0.0 & 0.0 & 0.9 & 9.7 \\
\hline \multirow[t]{2}{*}{$50-54$} & men & 8.2 & 12.3 & 2.5 & 0.0 & 13.9 & 36.8 \\
\hline & women & 5.0 & 11.7 & 5.8 & 0.0 & 9.2 & 31.7 \\
\hline \multirow[t]{2}{*}{$55-59$} & men & 24.7 & 40.7 & 5.5 & 3.7 & 16.0 & 90.6 \\
\hline & women & 37.5 & 24.6 & 4.3 & 1.8 & 13.5 & 81.7 \\
\hline \multirow[t]{2}{*}{$60-64$} & men & 52.4 & 75.9 & 7.0 & 5.5 & 41.5 & 182.2 \\
\hline & women & 74.9 & 33.5 & 12.5 & 4.7 & 25.0 & 150.6 \\
\hline \multirow[t]{2}{*}{$\geqq 65$} & men & 10.7 & 19.1 & 1.9 & 3.1 & 11.6 & 46.4 \\
\hline & women & 21.7 & 8.0 & 2.7 & 2.5 & 6.7 & 41.7 \\
\hline total & & 10.1 & 9.9 & 1.7 & 1.0 & 6.2 & 29.0 \\
\hline
\end{tabular}

Table 6 Comparison of the ratios of causes of presenile dementia in Japan

\begin{tabular}{|c|c|c|c|c|c|c|c|c|}
\hline & & $\begin{array}{l}\text { Number of } \\
\text { patients }\end{array}$ & $\begin{array}{c}\text { Ratio of } \\
\text { women (\%) }\end{array}$ & AD (\%) & VD (\%) & FTLD (\%) & $\begin{array}{c}\text { PDD/ } \\
\text { DLB (\%) }\end{array}$ & others (\%) \\
\hline $\begin{array}{l}\text { Ohshiro et al. } \\
(1994)^{4)}\end{array}$ & Cli & 100 & - & 17 & 45 & $1 *$ & $2 * *$ & 35 \\
\hline $\begin{array}{l}\text { Miyanaga et al. } \\
(1997)^{1)}\end{array}$ & Com & 1,204 & 34 & 17 & 44 & $1 * * *$ & $2 * *$ & 36 \\
\hline $\begin{array}{l}\text { Yokota et al. } \\
(2005)^{2)}\end{array}$ & Cli & 34 & 62 & 38 & 24 & 15 & 3 & 20 \\
\hline $\begin{array}{l}\text { Shinagawa et al. } \\
(2007)^{3)}\end{array}$ & Cli & 185 & 49 & 39 & 13 & 21 & 1 & 26 \\
\hline Asada $(2008)^{5)}$ & Com & 514 & 41 & 29 & 49 & 3 & 4 & 15 \\
\hline Konagaya et al. & Com & 796 & 45 & 34 & 36 & 6 & $3 * *$ & 22 \\
\hline
\end{tabular}

Cli: Clinic-based study, Com: Community-based study, AD: Alzheimer's disease, VD: vascular dementia, FTLD: frontotemporal lobar degeneration, PDD/DLB: Parkinson disease with dementia and dementia with Lewy bodies

*: reported as motor neuron disease, **: reported as Parkinson disease, ***: reported as Pick disease

にくらべて調查の範囲が広く, 病院や介護保険施設を多く擁 している人口が多い大都市をふくむ県全体を網羅した調査で あり，有意義であると考える。

性別に関して本研究では, 二次調査で重複を調整した後の 18 歳から 64 歳までの 796 人では, 男性は女性より多く, 女性 の割合は $45 \%$ であった。調査時点で 65 歳以上の対象者をふ くめた 1,092 人についても女性の割合は $47.2 \%$ と男性より少

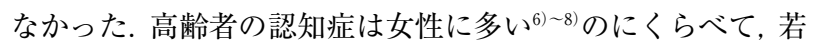
年認知症の特徵と考えられた ${ }^{9}$. 既報告では, Yokota らの報告 を除いて，女性の割合は $50 \%$ 以下である (Table 6). さらに 宮永らの報告以外では，女性の割合は $40 \%$ 代となっており， 男性が若干上回っている. 高齢者ではもともと, 女性の人口が 多く，また，女性に多いとされている $\mathrm{AD}$ は年龄が上がると

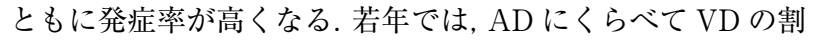
合が多〈147710), 脳血管障害は男性に多いことが知られてい る. また, その他の頭部外傷やアルコール依存症など多様な原
因疾患においても, 男性に多い疾患があり, 男女比に影響して いると考えられる.

調査時年齢は, 5 歳ごとの層化年齢別では, 60〜 64 歳がもっ とも多く, 次いで 65 歳以上であるが, 発症が 64 歳以下である ばあい, 65 歳に達するまでに死亡する人も多くいると考えら れる．また，人口 10 万人当たりの対象者数からも， 60〜 64 歳の層がもっとも人数が多く, 若年発症の認知症者の数はこ の年齢層がもっとも多いといえる.これは, 後述の発症年齢と 合わせると, 高齢発症の認知症と同様に若年認知症の発症数 および対象者数は年齢とともに増加すると考えられる.

発症年齢に関する先行研究は多くない中で, 発症年齢の平 均值が 50.3 歳とする報告がある ${ }^{11}$ が, 回収率のばらつきや, 現 在では認知症にはふくまれない疾患もふくめていることが影 響している可能性がある. Shinagawa らの報告では, 受診時 平均年齢と受診までに要した平均月数から，発症年齢はおお よそ53歳と考えられ，われわれの報告とほぼ同様である.ま 
た Fujihara らは, 141 人の若年認知症患者の発症年齢を 5 歳ごとに層化して分析し, 男性では 55〜 59 歳, 女性では 60 65 歳がもっとも多かったとしている ${ }^{11)}$. Harvey らは, 調査 時年齢が 65 歳以上の人をふくめた若年認知症 185 人を分析 して, 発症年齢は 60～64 歳が $32 \%$ ともっとも多く, 次いで 55〜59 歳の $27 \%$ であったと報告している ${ }^{12}$. 一般的に認知症 の発症率は，高年齢になるほど高いが，本調査では，60～64 歳と 55〜59 歳の発症がほぼ同数あったが, この理由について は, 発症年齢自体が家族や本人からの聞き取りであり誤差が 生じやすいこと, 施設や医療機関の利用者について職員や医 師が回答した調査であるためのバイアスの影響の可能性があ ること, 本調査の回収率が $100 \%$ ではなかったこと, 回答者の 中でも発症年齢について無回答が多かったことなどが考えら れる。

原因疾患は, 全体では AD 34.9\%, VD 34.1\%, FTD 5.9\%, PD3.6\%の順であった. 男性ではVD がもっとも多く, 次いで $\mathrm{AD}$ であり, 女性では $\mathrm{AD}$ がもっとも多く, 次いで $\mathrm{VD}$ と男女 による違いがみられた（Fig. 1)。宮永らは，男性ではVDが もっとも多く 47\%, 次いで頭部外傷 13\%, AD $12 \%$, 女性で もVDがもっとも多く $41 \%$, 次いで AD 26\% であったと報 告している1). Table 6 に示した日本の既報告では, ADの割 合は $17 \%$ から $39 \%$ であ. 1990 年代の報告では $\mathrm{AD}$ は $17 \%$ で, VD が約 $45 \%$ ともっとも多い原因疾患であったが, 2005 年以降の報告では $\mathrm{AD}$ は $29 \%$ から $39 \%$ と増加してい る. また, 調査方法別にみると, Community-based ではおお むね VD が多く， Clinical-based では AD が多くなっている. Clinical-based においては, FTLDの割合が高く, これらの専 門機関においては, 神経変性疾患が詳細な診断基準の元, 把握 されていると考えられる．朝田とわれわれの報告では， $\mathrm{AD}$ より，VDが多いが，その差は朝田らのほうが極端である ${ }^{5)}$. $\mathrm{AD}$ は高齢者の認知症の原因疾患としてもっとも多い ${ }^{133}$ が, 若年認知症の原因疾患としても，以前に指摘されているより 多いことがわかった。 しかし, 年齢別にみると, 40 歳未満で は $\mathrm{AD}$ は抢らず, 年齢が上がるにつれて $\mathrm{AD}$ の割合が増加し た。

今回の報告は, 既報告にくらべて調査の範囲が広く, 病院や 介護保険施設を多く擁している人口が多い大都市をふくむ県 全体を網羅した調查であり, 若年認知症の実態を把握しえた と考えられ，以下の点を明らかにした．1）若年認知症は高齢 者の認知症とはことなり, 男性のほうが若干多い傾向にあっ た. 2) 発症年齢は, 55〜 59 歳と 60～64 歳がほぼ同数であっ た. 3) 原因疾患には性差があり, 男性では VD, 女性では $\mathrm{AD}$ が多かった。 4) 原因疾患の割合は, 調査年代や調査方法によ り大きく影響される.

謝辞: 本研究は平成 18 年度厚生労働省老人保健健康増進等事 業費によった，調查にご協力いただいたすべての方々に感謝する.

\section{文献}

1）宮永和夫, 米村公江, 一ノ渡尚道ら：日本における若年期 および初老期の痴呆性疾患の実態について，老年精神医 学雑誌 $1997 ; 8: 1317-1331$

2) Yokota O, Sasaki K, Fujisawa Y, et al: Frequency of early and late-onset dementias in a Japanese memory disorders clinic. Eur J Neurol 2005; 12: 782-790

3) Shinagawa S, Ikeda M, Toyota Y, et al: Frequency and clinical characteristics of early-onset dementia in consecutive patients in a memory clinic. Dement Geriatr Cogn Disord 2007; 24: 42—47

4) 大城 等, 黒沢洋一, 岩井伸夫ら：鳥取県に扔ける初老期 の痴呆の有病率. 日本公衛誌 $1994 ; 5: 424-427$

5) 朝田 隆：総括研究報告. 厚生労働科学研究費補助金(長 寿科学総合研究)「若年性認知症の実態と対応の基盤整備 に関する研究」平成 19 年度報告書, pp 1-26

6) Hofman A, Rocca WA, Brayne C, et al: The prevalence of dementia in Europe: a collaborative study of 1980-1990 findings. Eurodem Prevalence Research Group. Int J Epidemiol 1991; 20: 736-748

7) Ott A, Breteler MMB, van Harskamp F, et al: Incidence and risk of dementia. The Rotterdam Study. Am J Epidemiol 1998; 147: 574-580

8) Andersen K, Launer LJ, Dewey ME, et al: Gender differences in the incidence of $\mathrm{AD}$ and vascular dementia. EURODEM studies. Neurology 1999; 53: 1992-1997

9) Harvey RJ, Skelton-Robinson M, Rossor MN: The prevalence and causes of dementia in people under the age of 65 years. J Neurol Neurosurg Psychiatry 2003; 74: 12061209

10) Vraamark Elberling T, Stokholm J, Høgh P, et al: Diagnostic profile of young and middle-aged memory clinic patients. Neurology 2002; 59: 1259-1262

11) Ott A, Breteler MMB, van Harskamp F, et al: Prevalence of Alzheimer's disease and vascular dementia: association with education. The Rotterdam study. Br Med J 1995; 310: $970-973$

12) Fujihara S, Brucki SMD, Rocha MSG, et al: Prevalence of presenile dementia in a tertiary outpatient clinic. Arq Neuro-Psiquiatr 2004; 62: 592-595

13) Harvey RJ: Young Onset Dementia: Epidemiology, clinical symptoms, family burden, support and outcome. The Dementia Research Group, Imperial College School of Medicine, London, 1998, pp 68-70 


\author{
Abstract \\ Frequency and clinical characteristics of the individuals with presenile dementia in Aichi prefecture

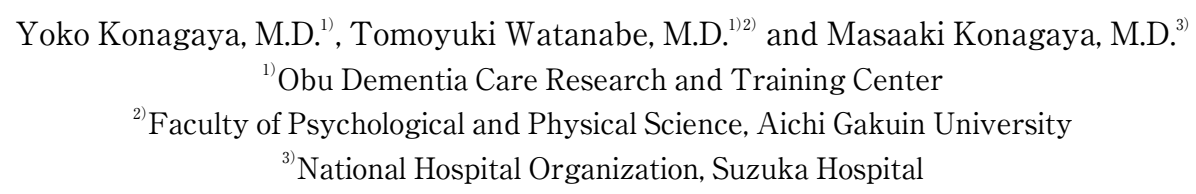

The aim of this study is to investigate the frequency, causes, and clinical characteristics of individuals with presenile dementia with an age of onset less than 65 years. A staged questionnaire survey was performed among all hospitals and clinics, all faculties of care and welfare services, and all local governmental offices in Aichi prefecture. The response rate of the primary survey was $62.3 \%$, and that of the secondary survey was $90.1 \%$. The number of people with presenile dementia after adjusting for duplicated subjects was 1,092 (569 men, 520 women and 3 of unknown gender). The average age was $60.7 \pm 7.1$ (mean \pm SD) years, and age of onset was $55.1 \pm 7.8$ years. Vascular dementia (VD) was the most frequent cause in men (42.2\%), followed by Alzheimer's disease (AD: $24.8 \%$ ), frontotemporal dementia (FTD: $4.6 \%$ ) and Parkinson disease (PD: 3.8\%). In women, AD was the most common (45.8\%), followed by VD (25.4\%), FTD (7.4\%) and PD (3.4\%). Overall, AD and VD were the most common causes of presenile dementia, followed by FTD and PD. The highest prevalence of presenile dementia was seen in the age range of 60-64 years old. This was true for both men and women.

(Clin Neurol, 49: 335-341, 2009)

Key words: people with presenile dementia, Alzheimer's disease, vascular dementia, epidemiology, Aichi prefecture 